\title{
Estimating Typhoid Fever Risk Associated with Lack of Access to Safe Water: A Systematic Literature Review
}

\author{
Vijayalaxmi V. Mogasale, ${ }^{1}$ Enusa Ramani, ${ }^{2}$ Vittal Mogasale $\mathbb{D},{ }^{2}$ \\ Ju Yeon Park, ${ }^{3}$ and Thomas F. Wierzba ${ }^{4,5}$ \\ ${ }^{1}$ Epidemiology Unit, International Vaccine Institute, Seoul, Republic of Korea \\ ${ }^{2}$ Policy and Economic Research Department, International Vaccine Institute, Seoul, Republic of Korea \\ ${ }^{3}$ Biostatistics and Data Management Department, International Vaccine Institute, Seoul, Republic of Korea \\ ${ }^{4}$ Development and Delivery Unit, International Vaccine Institute, Seoul, Republic of Korea \\ ${ }^{5}$ PATH, 455 Massachusetts Avenue NW, Suite 1000, Washington, DC, USA
}

Correspondence should be addressed to Vittal Mogasale; vmogasale@ivi.int

Received 28 December 2017; Accepted 28 May 2018; Published 4 July 2018

Academic Editor: Evelyn O. Talbott

Copyright (C) 2018 Vijayalaxmi V. Mogasale et al. This is an open access article distributed under the Creative Commons Attribution License, which permits unrestricted use, distribution, and reproduction in any medium, provided the original work is properly cited.

Background. Unsafe water is a well-known risk for typhoid fever, but a pooled estimate of the population-level risk of typhoid fever resulting from exposure to unsafe water has not been quantified. An accurate estimation of the risk from unsafe water will be useful in demarcating high-risk populations, modeling typhoid disease burden, and targeting prevention and control activities. Methods. We conducted a systematic literature review and meta-analysis of observational studies that measured the risk of typhoid fever associated with drinking unimproved water as per WHO-UNICEF's definition or drinking microbiologically unsafe water. The mean value for the pooled odds ratio from case-control studies was calculated using a random effects model. In addition to unimproved water and unsafe water, we also listed categories of other risk factors from the selected studies. Results. The search of published studies from January 1, 1990, to December 31, 2013 in PubMed, Embase, and World Health Organization databases provided 779 publications, of which 12 case-control studies presented the odds of having typhoid fever for those exposed to unimproved or unsafe versus improved drinking water sources. The odds of typhoid fever among those exposed to unimproved or unsafe water ranged from 1.06 to 9.26 with case weighted mean of 2.44 (95\% CI: 1.65-3.59). Besides water-related risk, the studies also identified other risk factors related to socioeconomic aspects, type of food consumption, knowledge and awareness about typhoid fever, and hygiene practices. Conclusions. In this meta-analysis, we have quantified the pooled risk of typhoid fever among people exposed to unimproved or unsafe water which is almost two and a half times more than people who were not exposed to unimproved or unsafe water. However, caution should be exercised in applying the findings from this study in modeling typhoid fever disease burden at country, regional, and global levels as improved water does not always equate to safe water.

\section{Introduction}

Typhoid fever is a systemic bacterial illness of public health importance. The disease is transmitted person to person due to fecal contamination of food and water [1]. The causative agent, Salmonella enterica serovar Typhi (S. Typhi), is exclusive to humans who are the natural host and reservoirs [2]. Humans can become chronic carriers and food handling practices among carriers can result in food contamination and S. Typhi transmission [2]. However, use of sewage contaminated water for irrigation and domestic use is considered critical in maintaining typhoid endemicity in developing countries as demonstrated in Santiago, Chile [2]. Since the major routes of transmission of typhoid fever are through drinking water or eating food contaminated with Salmonella typhi, the World Health Organization (WHO) recommends provision of safe water as one of the preventive measures for typhoid fever [2].

Defining and monitoring quality and ensuring water safety in low- and middle-income countries (LMICs) are challenging. The WHO defines microbiologically safe water based on the amount of Escherichia coli which should be 
TABLE 1: Improved and unimproved drinking water sources based on WHO/UNICEF Joint Monitoring Programme for water supply and sanitation [4].

\begin{tabular}{lc}
\hline Improved drinking water source & Unimproved drinking water source \\
\hline Piped water into dwelling, yard or plot & Unprotected spring \\
Public tap or standpipe & Unprotected dug well \\
Tubewell or borehole & Cart with small tank/drum \\
Protected dug well & Tanker-truck \\
Protected spring & Surface water \\
Rainwater collection & Bottled water from unimproved water source* \\
${ }^{*}$ Please refer to WHO/UNICEF Joint Monitoring Programme for water supply and sanitation [4] for details. Note that any microbiologically contaminated &
\end{tabular}

TABLE 2: Selection criteria for systematic literature review.

\section{Inclusion criteria}

(i) Publications listed from January 1, 1990 to December 31, 2013

(ii) Studies in English language

(iii) Research conducted in human subjects

(iv) Studies listed in PubMed database or Embase database or WHO website or PAHO website

(v) Study designs: case-control, cohort, randomized control trials

(vi) At least one water related exposure variable that could be categorized either as improved or unimproved drinking water source [4]

(vii) Water is consumed by drinking

\section{Exclusion criteria}

(i) Descriptive cross sectional studies that did not present odds ratio, case reports and case series

(ii) Studies that did not present water related risk-factors

(iii) Studies conducted in typhoid non-endemic area are excluded in the estimation of pooled odds ratio

$0 \mathrm{CFU} / 100 \mathrm{ml}[3]$ suggesting there should not be any fecal contamination. Continuous monitoring of the microbiologically safe water requires periodic laboratory testing of water sources which is difficult in resource poor settings of LMICs. To simplify the process WHO-UNICEF Joint Monitoring Programme (JMP) has defined alternative indicators, "improved water" and "unimproved water" sources [4], which deemed to represent safe water and unsafe water, respectively (Table 1 ).

People who drink safe water are likely to have lower risk of typhoid fever compared to people drink unsafe water which is one of the several risk factors for typhoid fever. However, typhoid fever global disease burden estimates often extrapolate the incidence rates obtained from high-risk populations to rest of the populations $[5,6]$ which is likely to be an overestimation. Hence, it is necessary to correct the incidence rates while extrapolating the data collected from populations drinking unsafe water to population drinking safe water. But, there is no database that provides information on drinking safe water or unsafe water that can be used in global disease burden estimation. Alternately, there is global database available on access to improved water to populations [7] which can be used as a proxy for safe water consumption. Therefore, it is necessary to link the risk of unsafe water to unimproved water. Although a systematic review presented earlier has showed that the microbiological safety of improved water is inconsistent [8] but provides a measure of sanitary protection and it is the only dataset that can be applied at the global level for water-related risk correction.

While many studies have explored the risk of typhoid fever from unsafe water, there has not been a systematic review that presented pooled estimate of the quantitative risk. We conducted a systematic literature review to quantify the probability of symptomatic $S$. typhi infection among residents who consumed unimproved or unsafe water compared to residents who did not consume unimproved or unsafe water. The primary purpose of this review was to derive a quantitative value on excess risk of typhoid fever due to the consummation of unimproved or unsafe water which can be used as a correction factor in global disease burden estimates [6].

\section{Materials and Methods}

A systematic literature review was conducted independently by each of two researchers. Each researcher first identified studies on risk factors for typhoid fever and then selected from those publications, papers presenting water-related risks. The search results from two researchers were compared and any differences between them were resolved based on discussion and agreement. If unresolved, a third independent researcher made the final decision. All selected papers were reviewed by a third researcher before data extraction to confirm its adherence to inclusion and exclusion criteria.

To identify studies, in addition to searching primary databases, PubMed and Embase, searches were also made in WHO and Pan American Health Organization (PAHO) databases. The search was limited to studies published in English language, from January 1, 1990, to December 31, 2013. The detailed inclusion and exclusion criteria are provided in Table 2. The search terms used were ("typhoid" OR "typhoid fever" OR "Salmonella Typhi” OR “S. Typhi” OR "Salmonella infection" OR "enteric fever") AND ("risk factors" OR 
"predictive factors" OR "associated factors" OR "attributed factors" OR "exposure factors" OR "related factors" OR "predisposing factors"). Search results are documented in a PRISMA diagram [31].

To quantify the risk, we selected one risk factor from each case-control study that best represented either improved or unimproved water based on the definition provided by WHO/UNICEF-JMP (Table 1). If a water source in a study was identified as "improved," but was reported to be "microbiologically contaminated," we considered the water source as "unsafe." We extracted the odds ratio of typhoid fever among those who got exposed to unimproved water or unsafe water compared to those who did not get exposed. A meta-analysis was conducted to pool the odds ratio of methodologically similar studies using a Metafor Statistical Packages for $\mathrm{R}$, version 1.9-8 [32, 33]. According to the heterogeneity test such as $\mathrm{Q}$ statistics and $\mathrm{I}^{2}$ [33], the mean value for pooled odds ratio from case-control studies were calculated from a meta-analysis using random effects model with restricted maximum-likelihood estimator [33]. Cohort study findings were descriptively presented as they could not be combined with case-control study meta-analysis. We also descriptively summarized other risk factors that showed a statistically significant probability of symptomatic $S$. typhi infection from the selected studies for the better understanding of overall risk factors.

\section{Results and Discussion}

Our review yielded a total of 779 publications from the search databases (Figure 1). A total of 87 duplicates were removed, and 612 were excluded on title and abstract search because they lacked data on typhoid fever related risk factors. Full texts were accessed for remaining 80 papers. Of them, 58 were excluded as they either (a) did not contain water-related risk factors or (b) could not be classified into improved or unimproved water categories based on WHO-UNICEF-JMP definition or (c) descriptive cross- sectional studies that did not present odd ratio. There were no randomized control trials. Four cohort studies were presented descriptively [2730] as the risk could not be merged and summarized with majority case-control studies. Finally, we could include only case-control studies in the estimation of pooled odds ratio. Sensitivity analysis was conducted for the decision of study exclusion. At the beginning of the analysis, one study was automatically excluded due to zero-count cell [34] and another one was omitted by sensitivity analysis as an outlier [9]. Four studies had presented odds ratio for improved water which could not be combined with odds ratio for unimproved water because inverse odds of improved water are technically not the same as unimproved water [23-26]. We cannot assume that people unexposed to improved water are exposed to unimproved water. The pooled odds ratio presented below include 12 case-control studies from reported typhoid endemic regions and presented waterrelated risk factors.

3.1. Case-Control Studies. Of the 12 selected studies, five were from South Asia [12, 13, 19-21], four were from Southeast Asia
$[15-17,22]$, two were from Central Asia [11, 18], and one was from South-Central Europe [14]. The studies included were mostly conducted in urban settings (75.00\%) and only three were outbreak investigations $(25.00 \%$, Table 3$)$. There were 915 typhoid fever cases and 1,609 nontyphoid fever controls. The exposure to unimproved water was higher among cases $(62.95 \% ; \mathrm{n}=576 / 915)$ compared to controls $(46.30 \% ; \mathrm{n}=$ 745/1609) (Figure 2). Half of the cases-controls studies having improved water source were microbiologically contaminated and were considered unsafe water (Table 3). The odds of typhoid fever among those who were exposed to unimproved water or unsafe water were ranged from 1.06 to 9.26 with case weighted mean of 2.44 (95\% CI: 1.65 - 3.59) (Figure 3).

Besides water-related risk, the studies also listed other risk factors related to socioeconomic aspects, living condition, food consumption, knowledge and awareness about typhoid fever, and hygiene practices (Table 4).

3.2. Cohort Studies. Four cohort studies presented relative risk of typhoid fever attributable to exposure to unimproved water sources compared to improved water sources [27-30]. The risk of contracting typhoid fever in groups exposed to drinking from a government water supply tank in Rajasthan was 11.10 (95\% CI: 3.70 - 33.00) times greater than those in the nonexposed group [27]. Those who drank from combined sources of government tank, hand pump, and personal tube well were 3.75 (95\% CI: $1.02-13.80)$ times more likely at risk of typhoid than those not exposed to the three combined sources indicating contamination of these sources. On a floating island restaurant in France, those who drank piped water onboard from untreated River Seine source had no excess risk of typhoid fever compared to those unexposed to those sources ( $\mathrm{RR}=1.4095 \% \mathrm{CI}$ : $0.60-3.00)$ [28]. This study concluded that consumption of rice and chicken washed in tap water resulted in outbreak and found fecal contamination in the tap water which was untreated. In urban Karachi, univariate analysis showed that individuals who consumed tap or bottled water had same risk $(\mathrm{RR}=0.70$; $95 \% \mathrm{CI}$ : 0.44 - 1.11) of getting typhoid fever compared to those who did not use tap or bottled water [30]. However, using regression model, after adjusting for all covariates, the study found that overall risk of typhoid fever is lower among households using a safe drinking water source ( $\mathrm{RR}=0.63 ; 95 \% \mathrm{CI}: 0.41-0.99$ ). In Eastern Kolkata, the study found that a significantly lower proportion of households use tap water $(\mathrm{RR}=0.07$; $\mathrm{p}$ value $=$ $<0.001)$ in typhoid fever high-risk areas compared to typhoid fever low-risk areas [29].

3.3. Case-Control Studies Excluded from Meta-Analysis. The four excluded case-control studies that presented odds of exposure to improved water among typhoid fever cases compared to controls [23-26] when combined together did not show any significant association with water source $(\mathrm{OR}=$ 0.70 ; 95\% CI: $0.46-1.05$ ) (Figure 4). The risk factors selected from these four studies included utilization of municipal drinking water (OR $=0.75 ; 95 \% \mathrm{CI}: 0.31-1.84)$ in Diyarbakir, Turkey [23], utilization of piped water (OR $=1.00$; $95 \% \mathrm{CI}$ : 0.37 - 2.72) in Ujung Pandang, Indonesia [24], drinking piped water $(\mathrm{OR}=0.52$; 95\% CI: $0.23-1.16)$ in Jakarta, Indonesia 


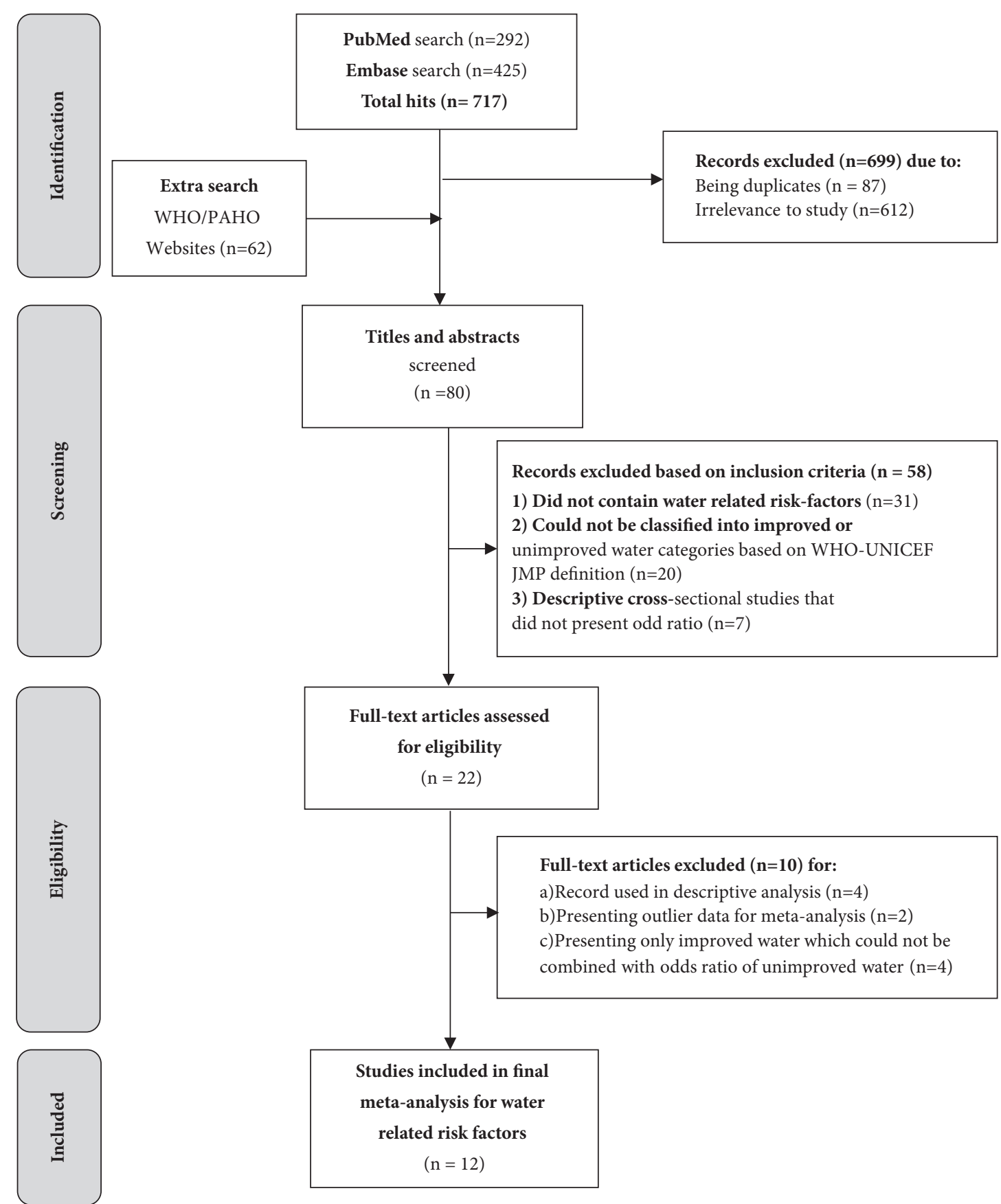

FIGURE 1: PRISMA diagram representing search results of typhoid fever risk factors.

[25], and utilization of tap water (OR $=0.69 ; 95 \% \mathrm{CI}: 0.34-$ 1.40) in Karachi, Pakistan [26].

Two case-control studies excluded from our investigations at the time of sensitivity analysis were from Thailand [34] and Malaysia [9]. In Thailand study, drinking unboiled spring water had 37.80 (95\% CI: 1.93 - 739.89) odds of typhoid fever compared to those who drank from either piped water, rain water, commercially bottled water, or water from wells. However, all typhoid fever cases were exposed to unboiled spring water. In Malaysian study, the accidental ingestion of water during swimming or bathing in a river had 32.78 (6.16
- 174.54) odds of getting typhoid fever compared to exposure from food items. In Figure 5 we have presented forest plot for odds ratio without excluding this study to show how its inclusion would have changed the results. Table 5 presents PRISMA checklist.

3.4. Discussion. The systematic review of literature yielded 12 case-control studies from 12 sites conducted in 10 different countries and presenting variables for water-related risk that could be categorized as unimproved water or unsafe water and associated with typhoid fever. This review demonstrates 
TABLE 3: Characteristics of case-control and cohort studies included in the systematic literature review.

\begin{tabular}{|c|c|c|c|c|c|c|c|}
\hline Publication year & Study year & Study site & $\begin{array}{l}\text { Study } \\
\text { setting }\end{array}$ & $\begin{array}{c}\text { Site } \\
\text { population }\end{array}$ & $\begin{array}{c}\text { Selected } \\
\text { unimproved/unsafe } \\
\text { water source }\end{array}$ & Reasons for typhoid fever & Source \\
\hline \multicolumn{8}{|c|}{ Case control studies } \\
\hline 1999 & 1997 & $\begin{array}{l}\text { Dushanbe, } \\
\text { Tajikistan }\end{array}$ & $\begin{array}{l}\text { Outbreak } \\
\text { in } \\
\text { endemic } \\
\text { area }\end{array}$ & Urban & $\begin{array}{c}\text { Water for home } \\
\text { obtained from outside } \\
\text { tap [10] } \\
\text { (contaminated } \\
\text { improved source = } \\
\text { unsafe) }\end{array}$ & $\begin{array}{l}\text { Water source contamination } \\
\text { Cessation of chlorination, } \\
\text { intermittent water supply } \\
\text { creating negative pressure and } \\
\text { contaminating water supply with } \\
\text { surrounding contaminants. }\end{array}$ & {$[11]$} \\
\hline 2013 & 2011 & $\begin{array}{l}\text { Kathmandu, } \\
\text { Nepal }\end{array}$ & Endemic & Urban & $\begin{array}{l}\text { Use of stone spout } \\
\text { water }\end{array}$ & $\begin{array}{l}\text { Multiple; drinking water spout } \\
\text { contamination with sewage, } \\
\text { contamination of stored water, } \\
\text { general sanitation issues such as } \\
\text { lack of toilets or lack of water to } \\
\text { flush toilets }\end{array}$ & [12] \\
\hline 2009 & 2007 & $\begin{array}{l}\text { West Bengal, } \\
\text { India }\end{array}$ & $\begin{array}{l}\text { Outbreak } \\
\text { in } \\
\text { endemic } \\
\text { area }\end{array}$ & $\begin{array}{l}\text { Urban } \\
\text { slum }\end{array}$ & $\begin{array}{c}\text { Drinking piped water } \\
{[10] \text { (contaminated }} \\
\text { improved source }= \\
\text { unsafe) }\end{array}$ & $\begin{array}{l}\text { Unchlorinated water supply } \\
\text { through pipes, drinking water } \\
\text { pipes close to open drainage and } \\
\text { intermittent water supply }\end{array}$ & [13] \\
\hline 1992 & 1990 & $\begin{array}{l}\text { Neapolitan } \\
\text { Area, Italy }\end{array}$ & $\begin{array}{l}\text { Outbreak } \\
\text { in } \\
\text { endemic } \\
\text { area }\end{array}$ & Urban & $\begin{array}{l}\text { Drinking non-potable } \\
\text { water }\end{array}$ & $\begin{array}{l}\text { Multiple; foodborne, sanitation, } \\
\text { and drinking water source } \\
\text { contamination due to sewage } \\
\text { exposure to municipal water } \\
\text { supply }\end{array}$ & [14] \\
\hline 2004 & 2000 & $\begin{array}{l}\text { Madaya } \\
\text { Township, } \\
\text { Myanmar }\end{array}$ & $\begin{array}{l}\text { Outbreak } \\
\text { in } \\
\text { endemic } \\
\text { area }\end{array}$ & Rural & $\begin{array}{l}\text { Drinking untreated } \\
\text { river water }\end{array}$ & $\begin{array}{c}\text { Drinking water contamination } \\
\text { with unchlorinated river water } \\
\text { which had direct sewage } \\
\text { drainage. }\end{array}$ & {$[15]$} \\
\hline 2005 & 2002 & $\begin{array}{l}\text { Son La } \\
\text { Province, N. } \\
\text { Vietnam }\end{array}$ & Endemic & Urban & $\begin{array}{l}\text { Drinking untreated } \\
\text { water }\end{array}$ & $\begin{array}{l}\text { Drinking water contamination } \\
\text { and consumption of } \\
\text { unchlorinated water (dislike for } \\
\text { chlorine smell) }\end{array}$ & [16] \\
\hline 2005 & 1996-1997 & $\begin{array}{l}\text { Dong Thap } \\
\text { Province, } \\
\text { Mekong } \\
\text { Delta, S. } \\
\text { Vietnam }\end{array}$ & Endemic & Urban & $\begin{array}{l}\text { Drinking unboiled } \\
\text { water }\end{array}$ & $\begin{array}{l}\text { Multiple; drinking river water } \\
\text { which had sewage (latrine) } \\
\text { drainage, drinking water sources } \\
\text { from deep wells and ponds } \\
\text { contaminated with drainage from } \\
\text { latrines situated in the proximity }\end{array}$ & {$[17]$} \\
\hline 2007 & $2002-2003$ & $\begin{array}{l}\text { Samarkand } \\
\text { Oblast, } \\
\text { Uzbekistan }\end{array}$ & Endemic & $\begin{array}{l}\text { Urban and } \\
\text { Rural }\end{array}$ & $\begin{array}{c}\text { Consumption of } \\
\text { unboiled surface } \\
\text { water outside the } \\
\text { home }\end{array}$ & $\begin{array}{l}\text { Water source contamination. The } \\
\text { drinking of un-boiled surface } \\
\text { water outside home during the } \\
\text { hot and dry summer months. }\end{array}$ & {$[18]$} \\
\hline 2009 & $2005-2006$ & $\begin{array}{l}\text { Darjeeling, } \\
\text { West Bengal, } \\
\text { India }\end{array}$ & Endemic & Rural & Stream water & $\begin{array}{l}\text { Multiple; foodborne, sanitation } \\
\text { issues, and drinking water source } \\
\text { contamination. Untreated water } \\
\text { supply from unprotected springs } \\
\text { and natural streams, untreated } \\
\text { water supply from venders. }\end{array}$ & [19] \\
\hline 2007 & 2003-2004 & $\begin{array}{l}\text { Dhaka slum, } \\
\text { Kamalapur, } \\
\text { Bangladesh }\end{array}$ & Endemic & $\begin{array}{l}\text { Urban } \\
\text { slum }\end{array}$ & $\begin{array}{l}\text { Drinking unboiled } \\
\text { water at home }\end{array}$ & $\begin{array}{l}\text { Multiple; sanitation issues, and } \\
\text { drinking water source } \\
\text { contamination. Partial } \\
\text { chlorination of municipal water } \\
\text { supply exposed to } \\
\text { contamination, drinking of } \\
\text { untreated water }\end{array}$ & [20] \\
\hline 1998 & 1994 & $\begin{array}{l}\text { Karachi, } \\
\text { Pakistan }\end{array}$ & Endemic & Urban & $\begin{array}{l}\text { Drinking water at } \\
\text { work (improved or } \\
\text { unimproved } \\
\text { unknown) }\end{array}$ & $\begin{array}{l}\text { Multiple; foodborne, sanitation } \\
\text { issues, and drinking water source } \\
\text { contamination at workplace }\end{array}$ & [21] \\
\hline
\end{tabular}


TABLE 3: Continued.

\begin{tabular}{|c|c|c|c|c|c|c|c|}
\hline Publication year & Study year & Study site & $\begin{array}{l}\text { Study } \\
\text { setting }\end{array}$ & $\begin{array}{c}\text { Site } \\
\text { population }\end{array}$ & $\begin{array}{c}\text { Selected } \\
\text { unimproved/unsafe } \\
\text { water source }\end{array}$ & Reasons for typhoid fever & Source \\
\hline 2001 & 1992-1994 & $\begin{array}{l}\text { Samarang, } \\
\text { Indonesia }\end{array}$ & Endemic & Urban & $\begin{array}{c}\text { Drinking } \\
\text { non-municipal water } \\
\text { source }\end{array}$ & $\begin{array}{l}\text { Multiple; foodborne, sanitation } \\
\text { issues, and drinking of } \\
\text { unchlorinated water from } \\
\text { venders }\end{array}$ & {$[22]$} \\
\hline 2005 & 2001-2003 & $\begin{array}{c}\text { Diyarbakir, } \\
\text { Turkey }\end{array}$ & Endemic & $\begin{array}{l}\text { Urban \& } \\
\text { rural }\end{array}$ & $\begin{array}{l}\text { Municipality drinking } \\
\text { water (contaminated } \\
\text { improved water } \\
\text { source }=\text { unsafe) }\end{array}$ & $\begin{array}{l}\text { Consumption of raw vegetables } \\
\text { irrigated with sewage water from } \\
\text { the city }\end{array}$ & {$[23]$} \\
\hline 1997 & $1990-1991$ & $\begin{array}{l}\text { Ujung } \\
\text { Pandang, } \\
\text { Indonesia }\end{array}$ & Endemic & Urban & $\begin{array}{c}\text { Piped water } \\
\text { (contaminated } \\
\text { improved water } \\
\text { source }=\text { unsafe) }\end{array}$ & Street food consumption & {$[24]$} \\
\hline 2004 & 2001-2003 & $\begin{array}{l}\text { Jakarta, } \\
\text { Indonesia }\end{array}$ & Endemic & Urban & $\begin{array}{c}\text { Piped water } \\
\text { (contaminated } \\
\text { improved water } \\
\text { source }==\text { unsafe) }\end{array}$ & $\begin{array}{l}\text { Hygienic practices such as no use } \\
\text { of soap for handwashing, sharing } \\
\text { of food, and no toilet in the } \\
\text { household and household } \\
\text { crowding at home }\end{array}$ & {$[25]$} \\
\hline 2008 & $1999-2001$ & $\begin{array}{l}\text { Karachi, } \\
\text { Pakistan }\end{array}$ & Endemic & Urban & $\begin{array}{c}\text { Piped water } \\
\text { (contaminated } \\
\text { improved water } \\
\text { source }=\text { unsafe })\end{array}$ & $\begin{array}{c}\text { Hygienic practices such as lack of } \\
\text { soap availability at handwashing } \\
\text { place, frequently eating outside } \\
\text { home and crowing at home }\end{array}$ & {$[26]$} \\
\hline \multicolumn{8}{|l|}{ Cohort studies } \\
\hline 2010 & 2007 & $\begin{array}{l}\text { Rajasthan, } \\
\text { India }\end{array}$ & $\begin{array}{l}\text { Outbreak } \\
\text { in } \\
\text { endemic } \\
\text { area }\end{array}$ & Rural & $\begin{array}{l}\text { Drinking water from } \\
\text { government tank, } \\
\text { hand pump and } \\
\text { personal tube well }\end{array}$ & $\begin{array}{l}\text { Contaminated sources due to an } \\
\text { open well supplying water to all } \\
\text { the three water supply facilities }\end{array}$ & {$[27]$} \\
\hline 2000 & 1998 & $\begin{array}{l}\text { River Seine, } \\
\text { Paris, France }\end{array}$ & Outbreak & Urban & $\begin{array}{l}\text { Drinking untreated } \\
\text { river water }\end{array}$ & Fecal contamination of tap water & {$[28]$} \\
\hline 2007 & $2003-2004$ & $\begin{array}{l}\text { Eastern } \\
\text { Kolkata, } \\
\text { India }\end{array}$ & Endemic & Urban & $\begin{array}{l}\text { Drinking unsafe } \\
\text { drinking water }\end{array}$ & NA & [29] \\
\hline 2012 & $2003-2006$ & $\begin{array}{l}\text { Karachi, } \\
\text { Pakistan }\end{array}$ & Endemic & Urban & Drinking tap water & NA & {$[30]$} \\
\hline
\end{tabular}

that unimproved water and unsafe water are associated with quantifiable odds of having typhoid fever. The result summary has been used in estimation of typhoid fever disease burden in LMICs [6] which demarcates high-risk population who would benefit maximum from typhoid interventions such as improving water and sanitation or vaccination. Other significant risk factors associated with the occurrence of typhoid fever were related to food consumption, socioeconomic status, hygiene and sanitary practices, living condition, and water storage and handling. These factors should be quantified in future analyses and should be included in future typhoid disease burden estimates. We have not accounted for environmental factors such as rain fall and temperatures, and anthropological measures such as age in this review which should be the other considerations in future disease burden studies.

The importance contaminated water as a major risk factor for typhoid fever is undisputable. During high-endemic period of typhoid fever in Santiago, Chile, the sewage contamination of food chain was demonstrated as the most important factor contributing to typhoid fever transmission, more than the typhoid carrier state in the family members [2]. The past epidemiological studies have demonstrated the importance of waterborne transmission, showing that only small inocula is sufficient for waterborne typhoid transmission, while foodborne transmission requires large inocula [2]. The key role of water and sanitation in typhoid fever transmission is further validated by a correlation between installment of water and sanitation system and decline in typhoid fever cases in industrialized countries. The progressive introduction of water filtration system in later 19th century was correlated with decline in typhoid fever mortality in United States of America (USA) [35]. A more decisive correlation was demonstrated in Philadelphia, USA, where water filtration system was serially introduced in six different districts between 1902 and 1909 [36]. When the condition of water supply and cause specific death rates for various diseases were examined, only typhoid fever deaths were found declining significantly following the introduction of water filtration system. 


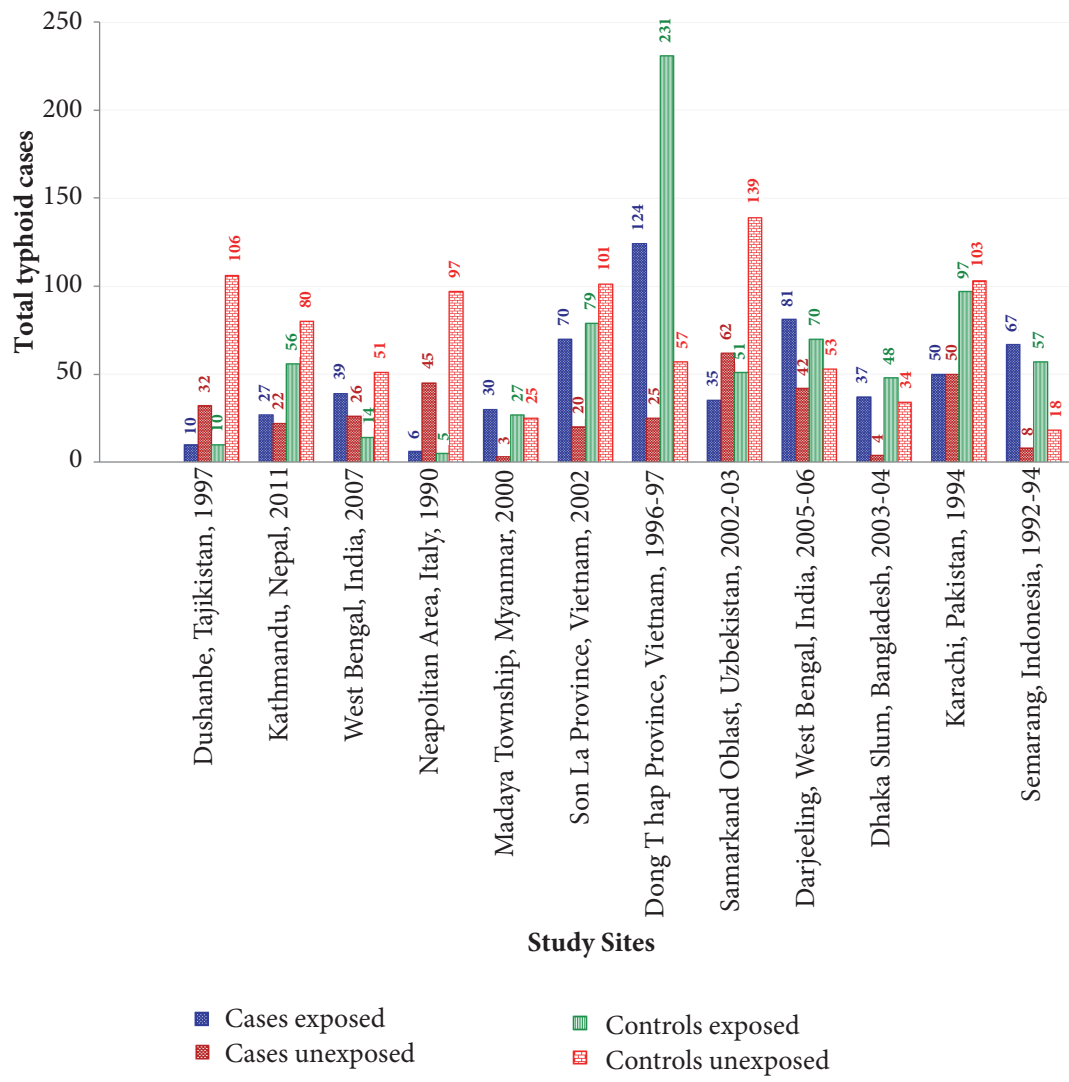

FIGURE 2: Exposure to unimproved water among typhoid fever cases and controls in selected studies.

Although poor water and sanitation system is not the only risk for typhoid transmission, its undisputable importance makes it a key risk factor in defining high-risk groups. Demarcating the typhoid fever risk groups is especially important in effectively targeting control measures such as vaccination programs. The $\mathrm{WHO}$ has recommended targeted vaccination of high-risk population with existing typhoid polysaccharide vaccine [1]. The significance of defining highrisk groups has increased with impending availability of typhoid conjugate vaccine [37], which may necessitate revisiting of WHO policies on vaccination strategies based on well-delineated target population. Most surveillance studies were conducted in known typhoid high-risk populations, which cannot be simply extrapolated to general population because their risk of typhoid fever is lower $[6,10]$. One of the several risk corrections that can be made in applying the typhoid fever incidence from high-risk population to general population is correct for water-related risk. However, there is no data available at global level of safe water drinking, but there is a database available on improved water and unimproved water [7]. Whereas improved water is representative of safe water and unimproved water is representative of unsafe water, the only available database can be applied at the global level for water-related correction in disease burden estimate. Computing the excess risk associated with the consumption of unsafe water or unimproved water will help in understanding the additional typhoid risk in certain populations and helps in measuring risk-differential typhoid fever incidence in different communities [6]. Such characterization of disease burden that can be linked to access to improved water can help in developing risk-based vaccination strategies and forecasting vaccine demand [38], identifying high-risk populations within countries and targeting vaccination to specific population, estimate its impact, calculate cost-effectiveness, and compare the efficiency of targeted vaccination versus vaccination of whole population.

3.5. Limitations. Our study has many limitations. First, we used a basic definition of improved water to represent safe water because this variable is officially reported by WHOUNICEF-JMP and a global data base is available that can be applied to LMICs in computing risk-differential typhoid fever disease burden. However, improved water does not always equate to safe water in many LMICs $[8,39]$ and in this paper half of the case-control studies reported microbiological contamination of improved water sources. Although microbiologically unsafe water sources were combined with unimproved water sources to estimate the excess risk of typhoid fever associated with unsafe water, the results may not be generalizable to country levels as this study represented only small number of countries. Similarly, caution should be applied in generalizing the finding to unimproved water as we included both unimproved and unsafe water in one category. Second, evidence from randomized control trials is valued the highest followed by longitudinal prospective cohort studies and case-control studies based on hierarchy 
Typhoid Control

Place, Country

Exposed Unexposed Exposed Unexposed

Odds Ratio $[95 \% \mathrm{CI}]$

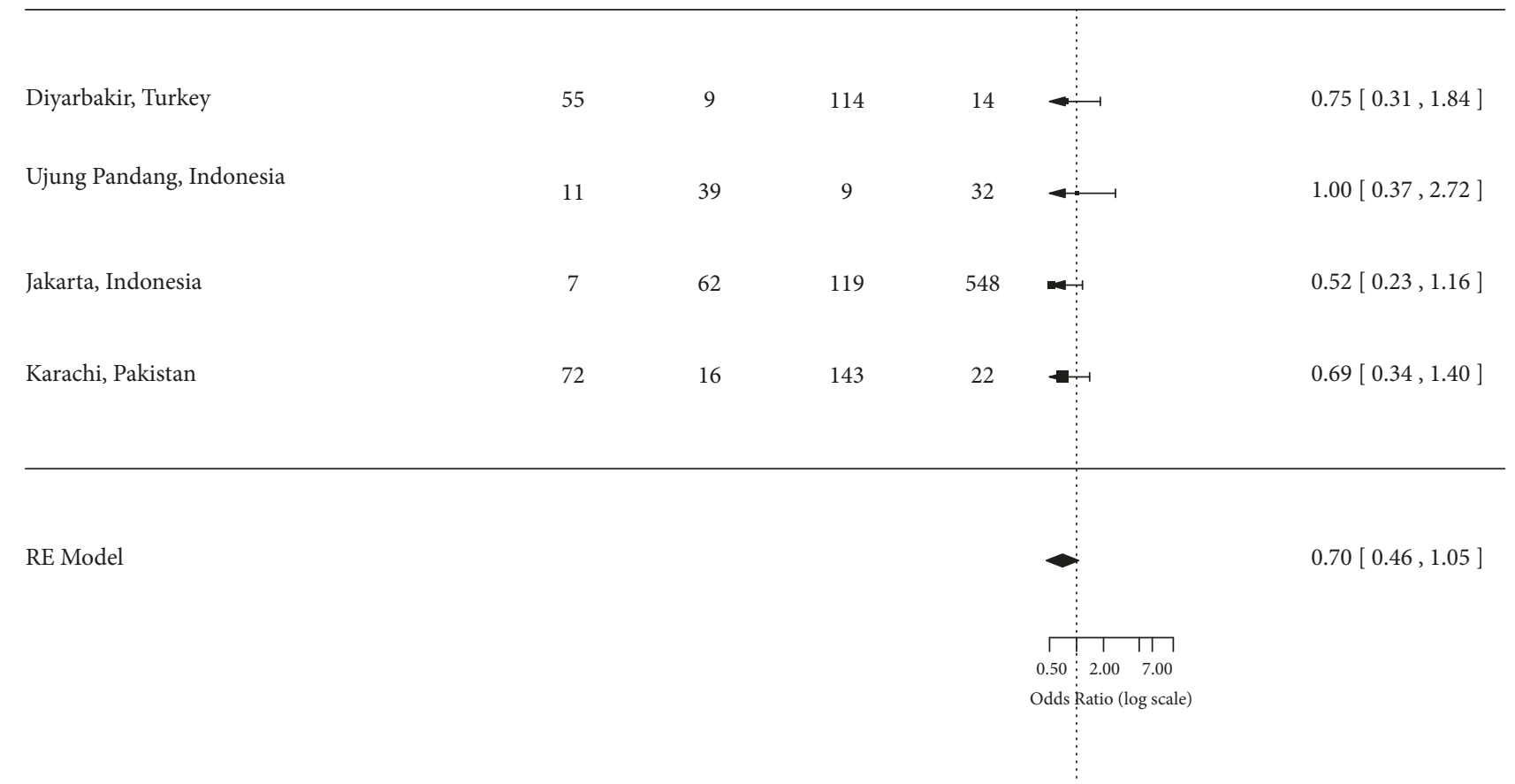

FIGURE 3: Forest plot showing odds ratio for typhoid fever for exposure and nonexposure to unimproved water.

of strength of evidence. We had to exclude four prospective cohort studies from meta-analysis approach because it was not possible to integrate the findings from those studies into the analysis. However, these cohort studies have suggested unimproved water as an important risk factor for typhoid fever. Third, it is worth noting that we used only one variable from each case-control study that best matched "unimproved water" to keep the analysis simple. It was challenging to categorize some water sources as improved or unimproved as they did not fit into any category and we had to choose one from the remaining variables. Selection of any other variables may have presented different values or may have resulted in ambiguous findings. Fourth, some of the water sources matched the definition of improved water but a statement from investigators revealed a case of clear contamination of improved water due to reasons such as proximity to sewage pipes and breakage in water supply systems made it necessary to reconsider the improved water as unsafe. This actually deviated from the definition of unimproved water but represented unsafe water which was critical measure for risk differentials. We had club these two categories in our analysis. Fifth, the typhoid fever risk from unsafe water is represented only by 12 studies in our systematic review. Number of studies is too small to generalize and mostly represent Asia. Caution is necessary in the application of results to global disease burden estimation. Sixth, we could have missed some vital papers on water-related risk factors for typhoid fever published in other languages besides English because of search criteria. Also, our search did not include unpublished literature such as conference abstracts, doctoral thesis, or meeting presentations. This may have resulted in publication bias. Lastly, we have used only those papers containing water-related risk factors in our review and, hence, many other significant typhoid fever risk factors outside selected papers may not have been captured in this review. We could have missed some important other risk factors not presented in these studies.

3.6. Conclusions. In conclusion, based on literature review we demonstrated that the exposure to unimproved water or unsafe water is significantly associated with typhoid fever. Our findings suggest that the population without access to safe water may be considered as one indicator to delineate high-risk population for typhoid related interventions. The high-risk population decided based on lack of access to safe water can be targeted for typhoid vaccination in addition to ongoing effort to improve water and sanitation infrastructure. Future research should focus on demarcating and quantifying other factors associated with typhoid fever in addition to water-related one, so that more comprehensive risk-association mapping based on geographical information system could be developed and used for targeting typhoid interventions. 


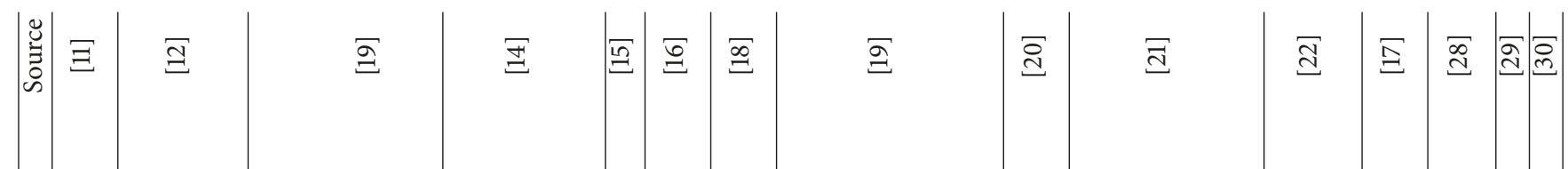

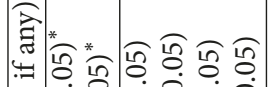

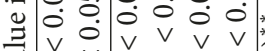

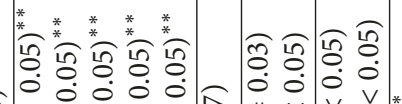

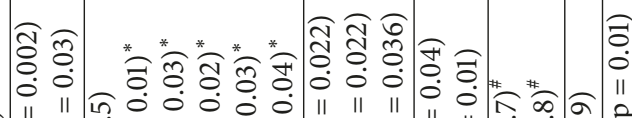

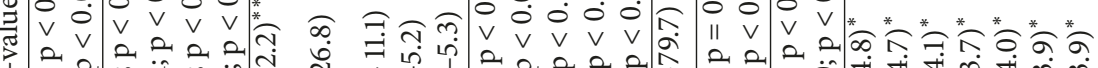

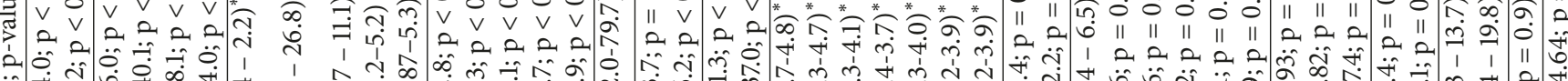

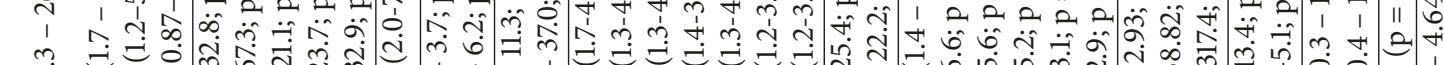

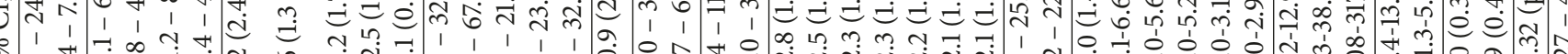

商

至

安

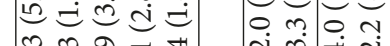

i

वे

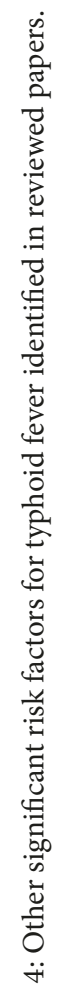

离

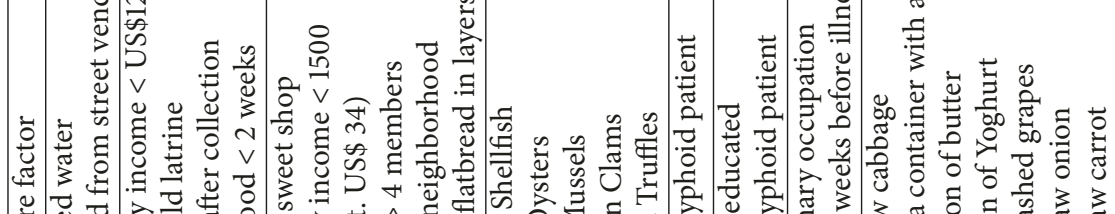

त्र.

त

के $\frac{m}{2} \frac{m}{m}$

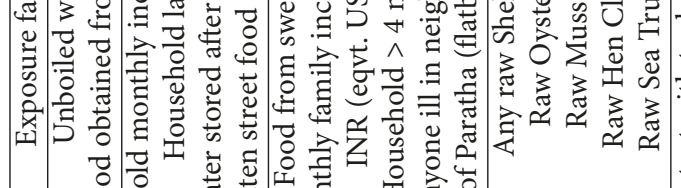

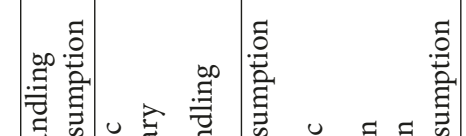

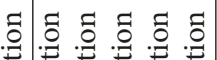

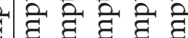

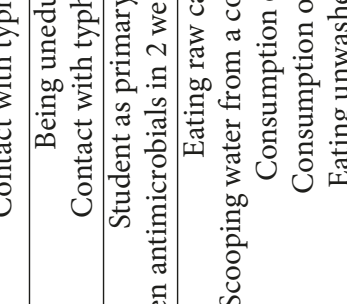

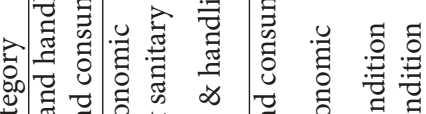

列

눙

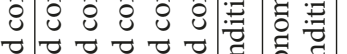

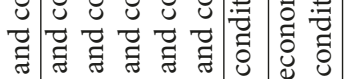

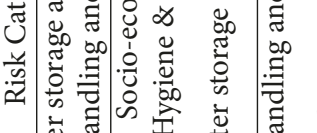

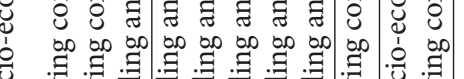
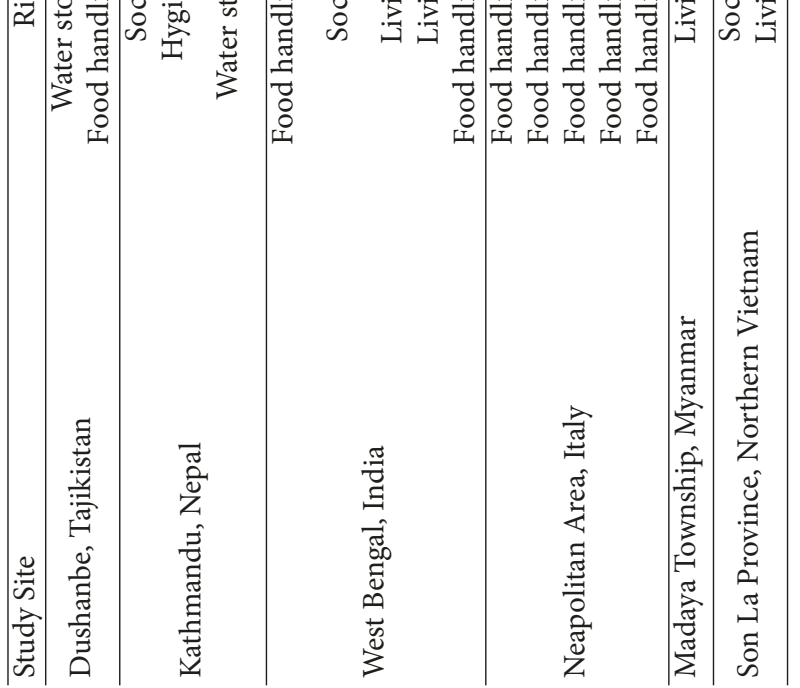

चี

氙

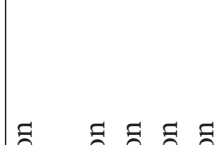

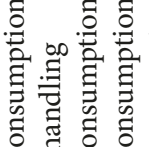

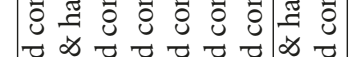

च

每

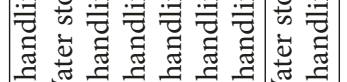

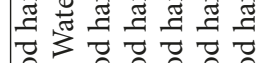

要

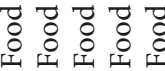

$3 \frac{7}{8}$

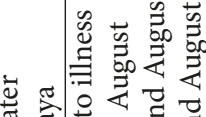

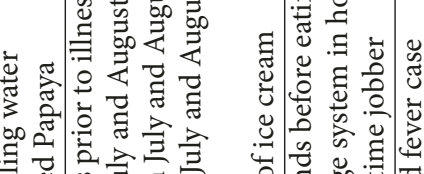

$\checkmark$ 造

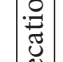

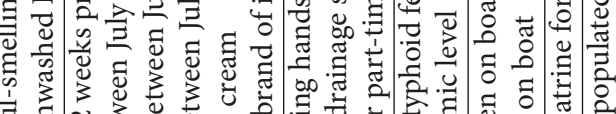

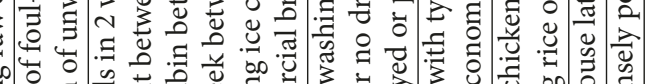

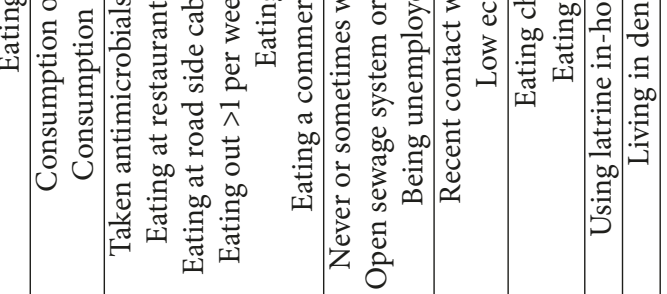

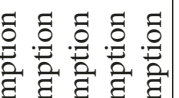

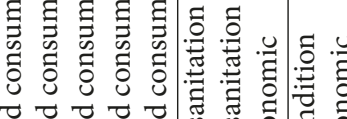

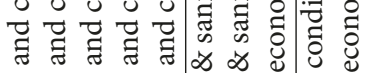

000000000000000

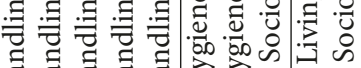

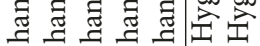

च च च च : च

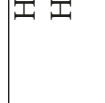

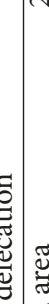
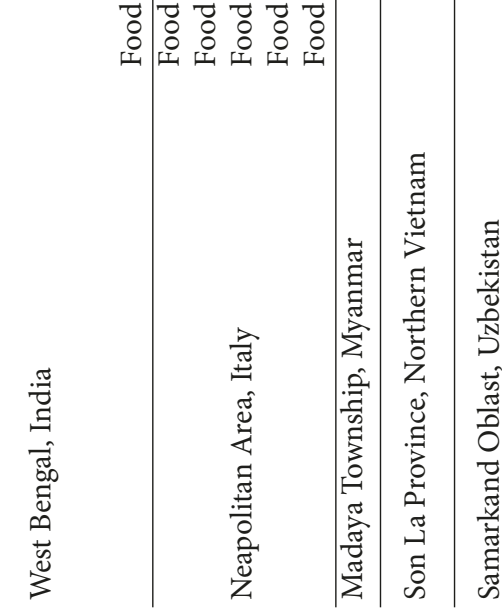

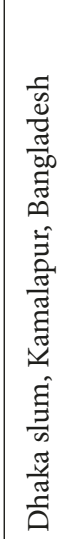
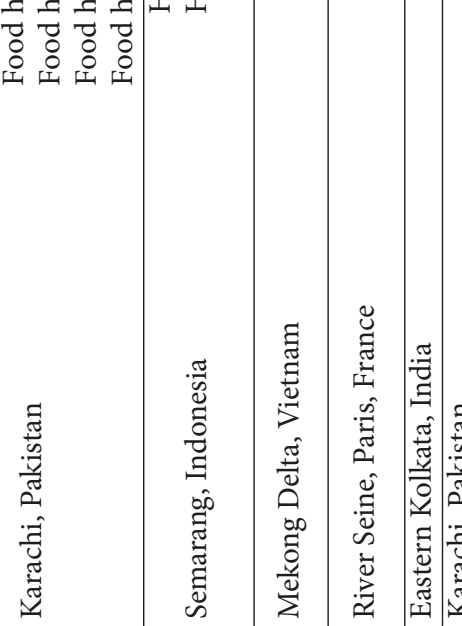

घี :

总蛋

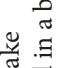

究

害

苛

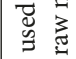

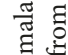

苞雚

毒 


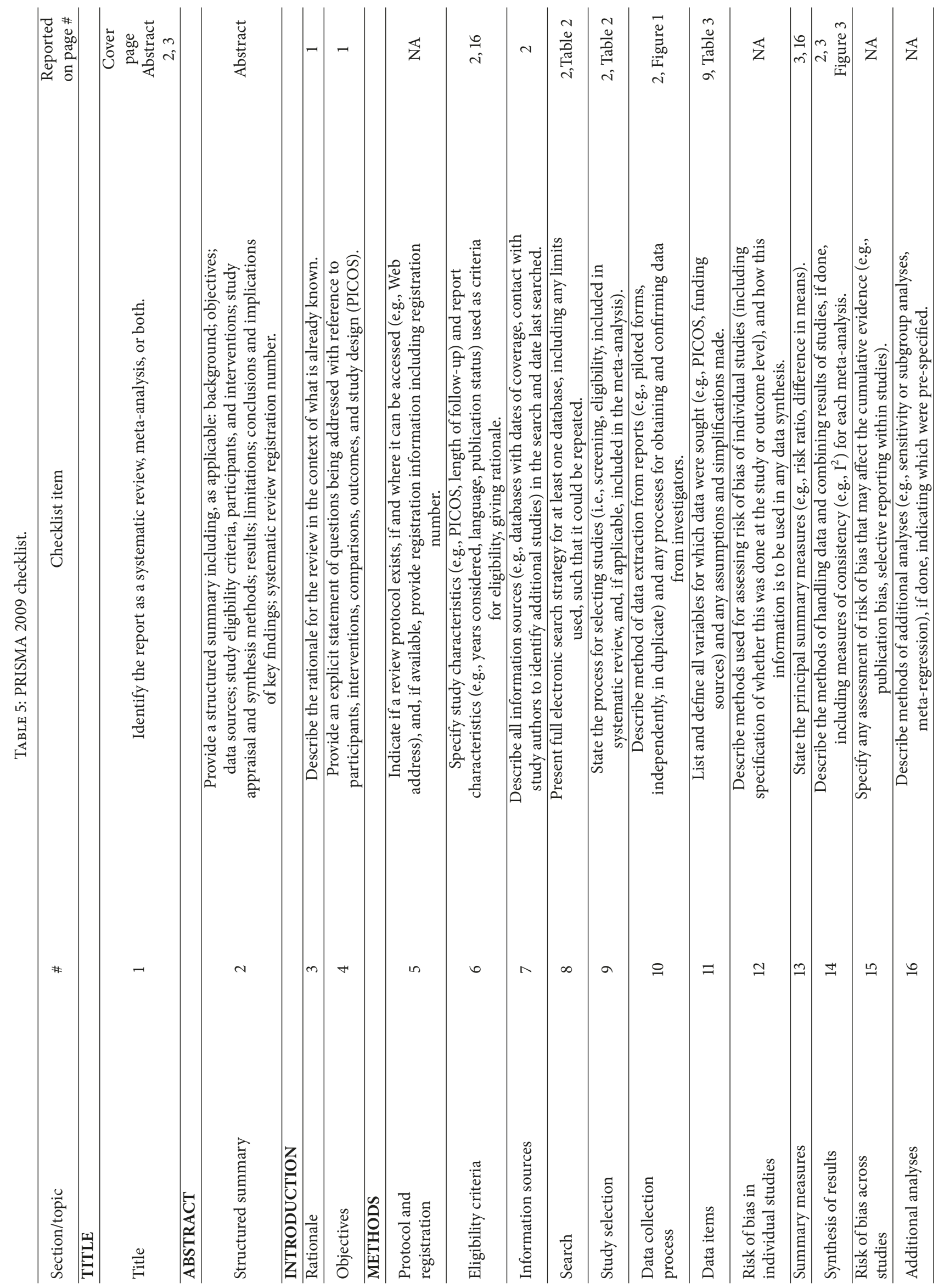




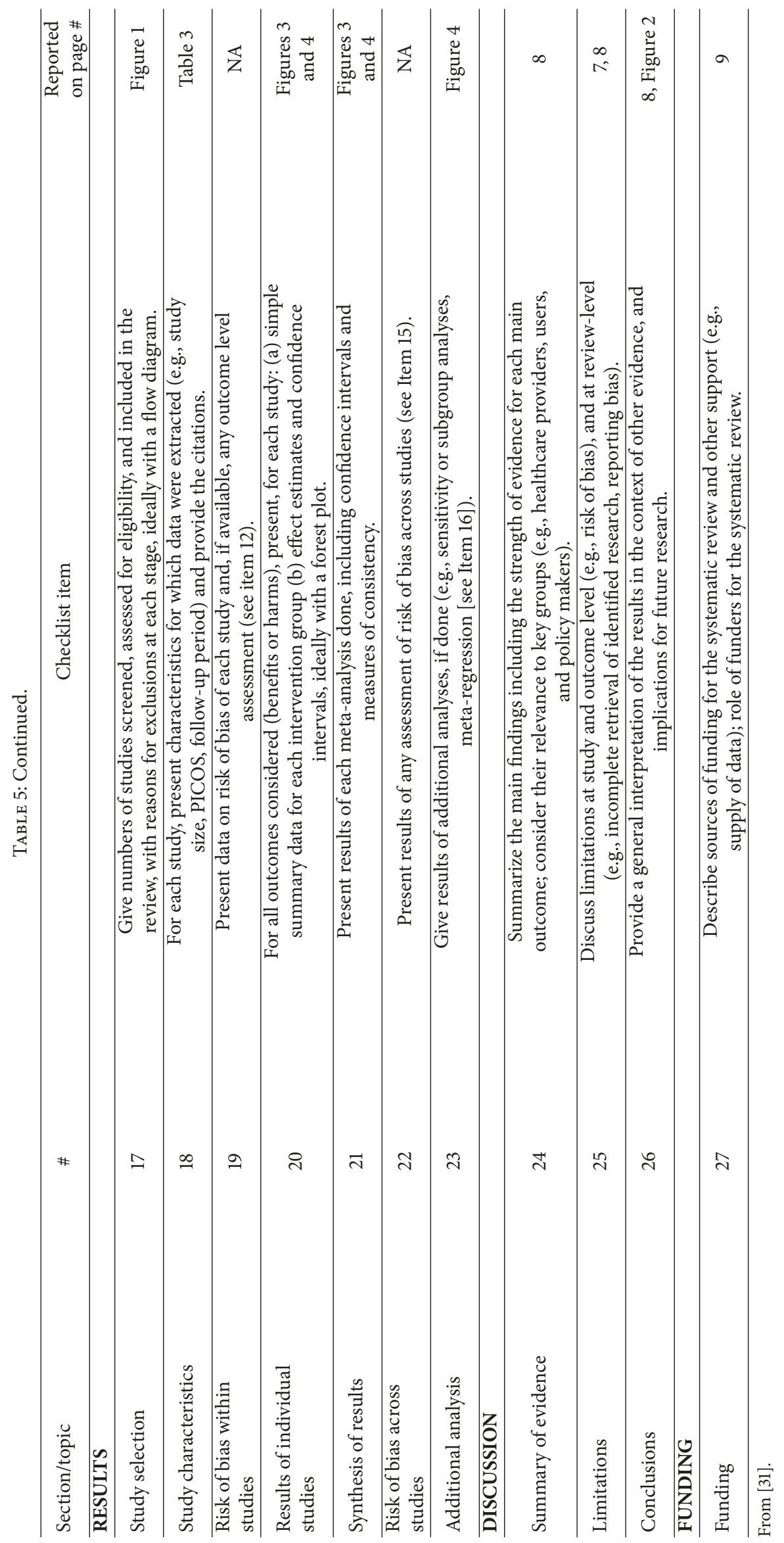


Typhoid Control

Place, Country

Exposed Unexposed Exposed Unexposed

Odds Ratio [95\% CI]

\begin{tabular}{|c|c|c|c|c|c|c|c|}
\hline Diyarbakir, Turkey & 55 & 9 & 114 & 14 & - & $\dashv$ & $0.75[0.31,1.84]$ \\
\hline Ujung Pandang, Indonesia & 11 & 39 & 9 & 32 & $\leftarrow$ & $\longrightarrow$ & $1.00[0.37,2.72]$ \\
\hline Jakarta, Indonesia & 7 & 62 & 119 & 548 & $\mathbf{m}$ & & $0.52[0.23,1.16]$ \\
\hline Karachi, Pakistan & 72 & 16 & 143 & 22 & + & & $0.69[0.34,1.40]$ \\
\hline \multirow[t]{4}{*}{ RE Model } & & & & & $<$ & & $0.70[0.46,1.05]$ \\
\hline & & & & & $\Gamma$ & 111 & \\
\hline & & & & & $0.50 \vdots$ & 2.007 .00 & \\
\hline & & \multicolumn{6}{|c|}{ Odds Ratio (log scale) } \\
\hline
\end{tabular}

FIGURE 4: Forest plot showing odds ratio for typhoid fever for exposure and nonexposure to improved water.

Typhoid Control

Place, Country, Data collection year

Exposed Unexposed Exposed Unexposed

Odds Ratio $[95 \%$ CI $]$

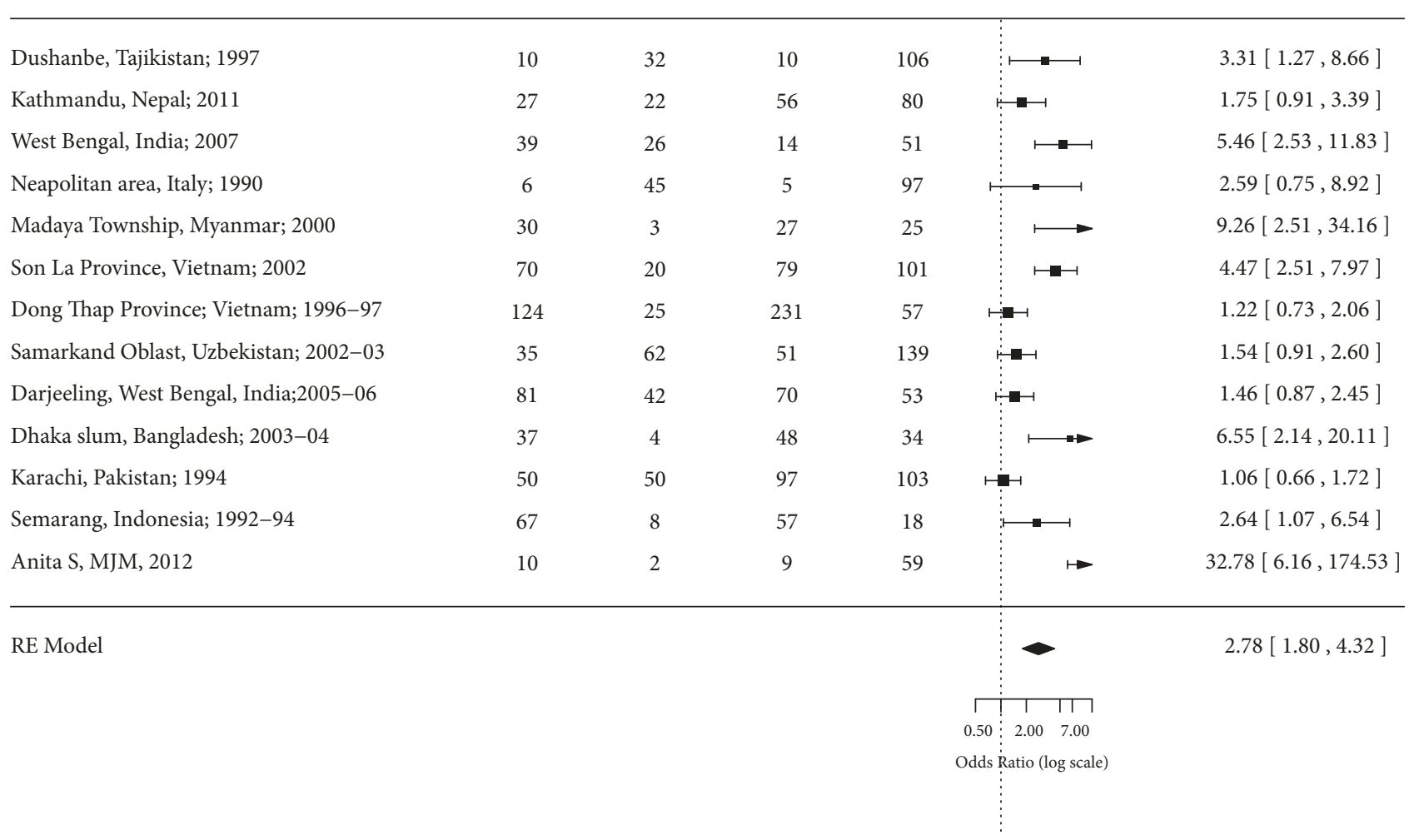

FIGURE 5: Forest plot showing odds ratio for typhoid fever for exposure and nonexposure to unimproved water after including one outlier study [9]. 


\section{Abbreviations}

S. Typhi: Salmonella enterica serovar Typhi

WHO: World Health Organization

LMICs: Low- and middle-income countries

CFU: Colony forming units

UNICEF: United Nations International Children

Emergency Relief Fund

JMP: Joint Monitoring Programme

PAHO: Pan American Health Organization

RR: $\quad$ Relative risk

OR: Odds ratio

USA: $\quad$ United States of America.

\section{Data Availability}

All data related to the research is available in the manuscript.

\section{Ethical Approval}

Research involved analysis of secondary data available in public domain. No human subjects are involved in this study. No ethical approval was sought.

\section{Conflicts of Interest}

The authors declare that they have no conflicts of interest.

\section{Authors' Contributions}

Vittal Mogasale has conceptualized the study, advised on developing search terms, served as the third reviewer in conducting the search, guided the analysis, interpreted the results, and rewrote the final manuscript. Vijayalaxmi V. Mogasale has served as first reviewer in conducting the search, developed search terms, extracted data, conducted the analysis, and wrote the first draft of manuscript. Enusa Ramani has served as second reviewer in conducting the search, assisted in data extraction and analysis, and reviewed and put together the final manuscript. Ju Yeon Park estimated weighted mean sensitivity using random effects model and drew forest plots. Thomas F. Wierzba provided overall technical advice for conceptualization and data analysis and reviewed and edited the manuscript. All authors have approved the final manuscript.

\section{Funding}

This work was supported the Vi-based Vaccines for Asia (VIVA) Initiative, which is funded by the Bill and Melinda Gates Foundation (Grant no. 417.01). International Vaccine Institute receives core funding by the Governments of Korea and Sweden.

\section{Acknowledgments}

The authors thank Dr. Jin Kyung Park for statistical support. This work was supported by the Vi-based Vaccines for Asia (VIVA) Initiative, which is funded by the Bill and Melinda
Gates Foundation (Grant no. 417.01). International Vaccine Institute received core funding from the Governments of Korea and Sweden.

\section{References}

[1] WHO, "Typhoid vaccines: WHO position paper," Weekly epidemiological record, vol. 83, no. 6, pp. 49-59, 2008.

[2] WHO, Background document:The diagnosis, treatment and prevention of typhoid fever, Geneva, Switzerland, 2003.

[3] WHO, Guidelines for drinking-water quality, vol. 3, Surveillance and control of community supplies, 2nd edition, 1997.

[4] WHO-UNICEF, "Types of drinking-water sources and sanitation, WHO/UNICEF Joint Monitoring Programme (JMP) for Water Supply and Sanitation," http://www.wssinfo .org/definitions-methods/watsan-categories.

[5] J. A. Crump, S. P. Luby, and E. D. Mintz, "The global burden of typhoid fever," Bulletin of the World Health Organization, vol. 82, no. 5, pp. 346-353, 2004.

[6] V. Mogasale, B. Maskery, R. L. Ochiai et al., "Burden of typhoid fever in low-income and middle-income countries: A systematic, literature-based update with risk-factor adjustment," The Lancet Global Health, vol. 2, no. 10, pp. e570-e580, 2014.

[7] "UN. Millenium Development Goals Indicators, UN Statistics Division: UN Statistics Division; 2010,” http://mdgs.un.org/ unsd/mdg/data.aspx.

[8] R. Bain, R. Cronk, J. Wright, H. Yang, T. Slaymaker, and J. Bartram, "Fecal Contamination of Drinking-Water in Low- and Middle-Income Countries: A Systematic Review and MetaAnalysis," PLoS Medicine, vol. 11, no. 5, Article ID e1001644, 2014.

[9] S. B. Anita, K. M. Amir, K. Fadzilah et al., "Risk factors for typhoid outbreak in Sungai Congkak recreational park, Selangor 2009," Medical Journal of Malaysia, vol. 67, no. 1, pp. 12-16, 2012.

[10] J.-S. Lee, V. V. Mogasale, V. Mogasale, and K. Lee, "Geographical distribution of typhoid risk factors in low and middle income countries," BMC Infectious Diseases, vol. 16, no. 1, article no. 732, 2016.

[11] J. H. Mermin, R. Villar, J. Carpenter et al., "A massive epidemic of multidrug-resistant typhoid fever in Tajikistan associated with consumption of municipal water," The Journal of Infectious Diseases, vol. 179, no. 6, pp. 1416-1422, 1999.

[12] A. Karkey, C. N. Thompson, N. Tran Vu Thieu et al., "Differential epidemiology of Salmonella Typhi and Paratyphi A in Kathmandu, Nepal: a matched case control investigation in a highly endemic enteric fever setting," PLOS Neglected Tropical Diseases, vol. 7, no. 8, Article ID e2391, 2013.

[13] R. Bhunia, Y. Hutin, R. Ramakrishnan, N. Pal, T. Sen, and M. Murhekar, "A typhoid fever outbreak in a slum of South Dumdum municipality, West Bengal, India, 2007: Evidence for foodborne and waterborne transmission," BMC Public Health, vol. 9, 2009.

[14] T. Stroffolini, G. Manzillo, R. De Sena et al., "Typhoid fever in the neapolitan area: A case-control study," European Journal of Epidemiology, vol. 8, no. 4, pp. 539-542, 1992.

[15] T. T. Aye and P. Siriarayapon, "Typhoid fever outbreak in Madaya Township, Mandalay Division, Myanmar, September 2000," Journal of the Medical Association of Thailand, vol. 87, no. 4, pp. 395-399, 2004. 
[16] H. H. Tran, G. Bjune, B. M. Nguyen, J. A. Rottingen, R. F. Grais, and P. J. Guerin, "Risk factors associated with typhoid fever in Son La province, northern Vietnam," Transactions of the Royal Society of Tropical Medicine and Hygiene, vol. 99, no. 11, pp. 819826, 2005.

[17] C. Luxemburger, C. M. Duc, M. N. Lanh et al., "Risk factors for typhoid fever in the Mekong delta, southern Viet Nam: A case-control study," Transactions of the Royal Society of Tropical Medicine and Hygiene, vol. 95, no. 1, pp. 19-23, 2001.

[18] P. Srikantiah, S. Vafokulov, S. P. Luby et al., "Epidemiology and risk factors for endemic typhoid fever in Uzbekistan," Tropical Medicine \& International Health, vol. 12, no. 7, pp. 838-847, 2007.

[19] P. K. Sharma, R. Ramakrishnan, Y. Hutin, P. Manickam, and M. D. Gupte, "Risk factors for typhoid in Darjeeling, West Bengal, India: Evidence for practical action," Tropical Medicine \& International Health, vol. 14, no. 6, pp. 696-702, 2009.

[20] P. K. Ram, A. Naheed, W. A. Brooks et al., "Risk factors for typhoid fever in a slum in Dhaka, Bangladesh," Epidemiology and Infection, vol. 135, no. 3, pp. 458-465, 2007.

[21] S. P. Luby, M. K. Faizan, S. P. Fisher-Hoch et al., "Risk factors for typhoid fever in an endemic setting, Karachi, Pakistan," Epidemiology and Infection, vol. 120, no. 2, pp. 129-138, 1998.

[22] M. Hussein Gasem, W. M. V. W. M. V. Dolmans, M. M. Keuter, and R. R. Djokomoeljanto, "Poor food hygiene and housing as risk factors for typhoid fever in Semarang, Indonesia," Tropical Medicine \& International Health, vol. 6, no. 6, pp. 484-490, 2001.

[23] S. Hosoglu, M. K. Celen, M. F. Geyik et al., "Risk factors for typhoid fever among adult patients in Diyarbakir, Turkey," Epidemiology and Infection, vol. 134, no. 3, pp. 612-616, 2006.

[24] J. P. Velema, G. Van Wijnen, P. Bult, T. Van Naerssen, and S. Jota, "Typhoid fever in Ujung Indonesia - High-risk groups and highrisk behaviours," Tropical Medicine \& International Health, vol. 2, no. 11, pp. 1088-1094, 1997.

[25] A. M. Vollaard, S. Ali, H. A. G. H. Van Asten et al., "Risk factors for typhoid and paratyphoid fever in Jakarta, Indonesia," Journal of the American Medical Association, vol. 291, no. 21, pp. 26072615, 2004.

[26] F. J. Siddiqui, S. R. Haider, and Z. A. Bhutta, "Risk factors for typhoid fever in children in squatter settlements of Karachi: A nested case-control study," Journal of Infection and Public Health, vol. 1, no. 2, pp. 113-120, 2008.

[27] P. K. Anand and R. Ramakrishnan, "Investigation of the outbreak of typhoid in a village of Thar Desert Rajasthan, India," Indian Journal of Medical Research, vol. 131, no. 6, pp. 799-803, 2010.

[28] M. Valenciano, S. Baron, A. Fisch, F. Grimont, and J. C. Desenclos, "Investigation of concurrent outbreaks of gastroenteritis and typhoid fever following a party on a floating restaurant, France, March 1998," American Journal of Epidemiology, vol. 152, no. 10, pp. 934-939, 2000.

[29] D. Sur, M. Ali, L. Von Seidlein et al., "Comparisons of predictors for typhoid and paratyphoid fever in Kolkata, India," BMC Public Health, vol. 7, article no. 289, 2007.

[30] M. I. Khan, R. L. Ochiai, S. B. Soofi et al., "Risk factors associated with typhoid fever in children aged 2-16 years in Karachi, Pakistan," Epidemiology and Infection, vol. 140, no. 4, pp. 665672, 2012.

[31] D. Moher, A. Liberati, J. Tetzlaff, and D. G. Altman, "Preferred reporting items for systematic reviews and meta-analyses: the PRISMA statement," PLoS Medicine, vol. 6, no. 7, Article ID e1000097, 2009.
[32] "Project R. The R Project for Statistical Computing [Internet]; 2009," https://www.r-project.org/.

[33] W. Viechtbauer, "Conducting meta-analyses in $\mathrm{R}$ with the metafor," Journal of Statistical Software, vol. 36, no. 3, pp. 1-48, 2010.

[34] W. Swaddiwudhipong and J. Kanlayanaphotporn, "A commonsource water-borne outbreak of multi-drug-resistant typhoid fever in a rural Thai community," Journal of the Medical Association of Thailand, vol. 84, no. 11, pp. 1513-1517, 2001.

[35] E. Meeker, "The improving health of the United States, 18501915," Explorations in Economic History, vol. 9, no. C, pp. 353$373,1971$.

[36] G. A. Condran and R. A. Cheney, "Mortality trends in Philadelphia: Age- and cause-specific death rates 1870-1930," Demography, vol. 19, no. 1, pp. 97-123, 1982.

[37] S. C. Szu, "Development of Vi conjugate - A new generation of typhoid vaccine," Expert Review of Vaccines, vol. 12, no. 11, pp. 1273-1286, 2013.

[38] V. Mogasale, E. Ramani, I. Y. Park, and J. S. Lee, "A forecast of typhoid conjugate vaccine introduction and demand in typhoid endemic low- and middle-income countries to support vaccine introduction policy and decisions," Human Vaccines \& Immunotherapeutics, vol. 13, no. 9, pp. 1-8, 2017.

[39] R. E. Quick, S. M. Montano, C. N. Mock et al., ““Improved” But Not Necessarily Safe: An Assessment of Fecal Contamination of Household Drinking Water in Rural Peru," The American Journal of Tropical Medicine and Hygiene, vol. 93, no. 3, pp. 501508, 2015. 


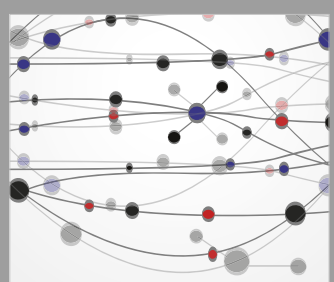

The Scientific World Journal
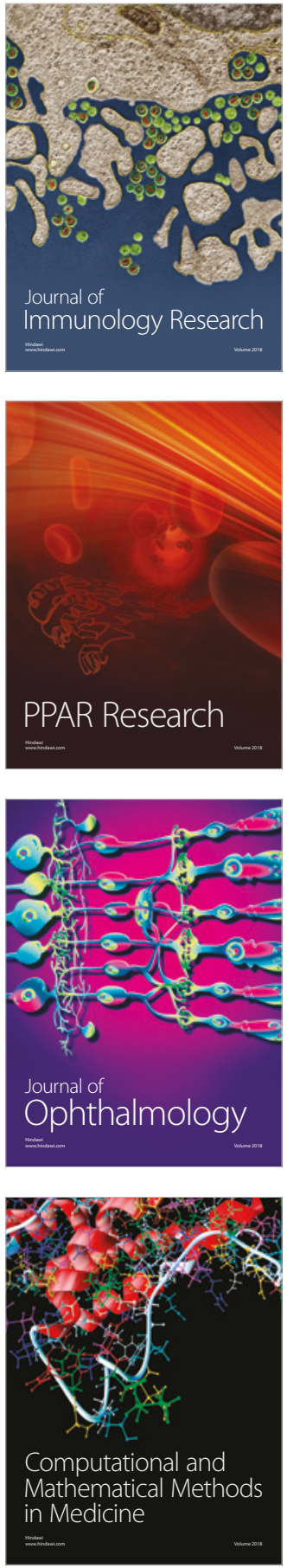

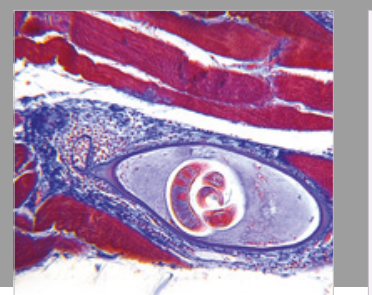

Gastroenterology Research and Practice

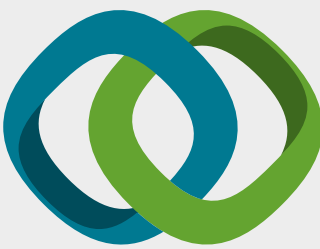

\section{Hindawi}

Submit your manuscripts at

www.hindawi.com
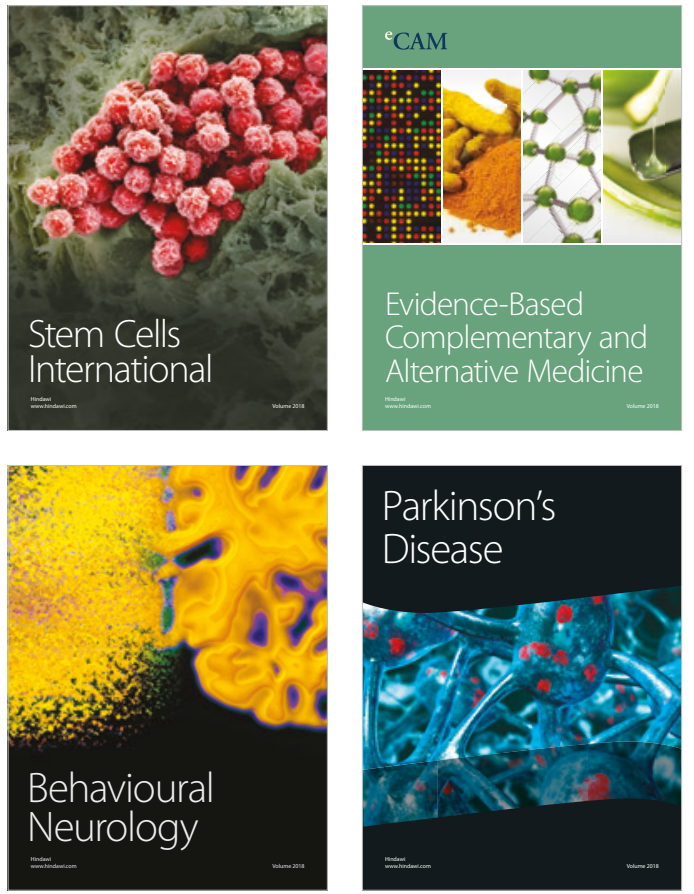

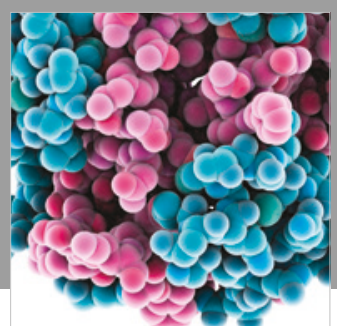

ournal of

Diabetes Research

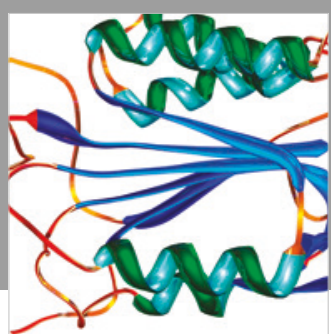

Disease Markers
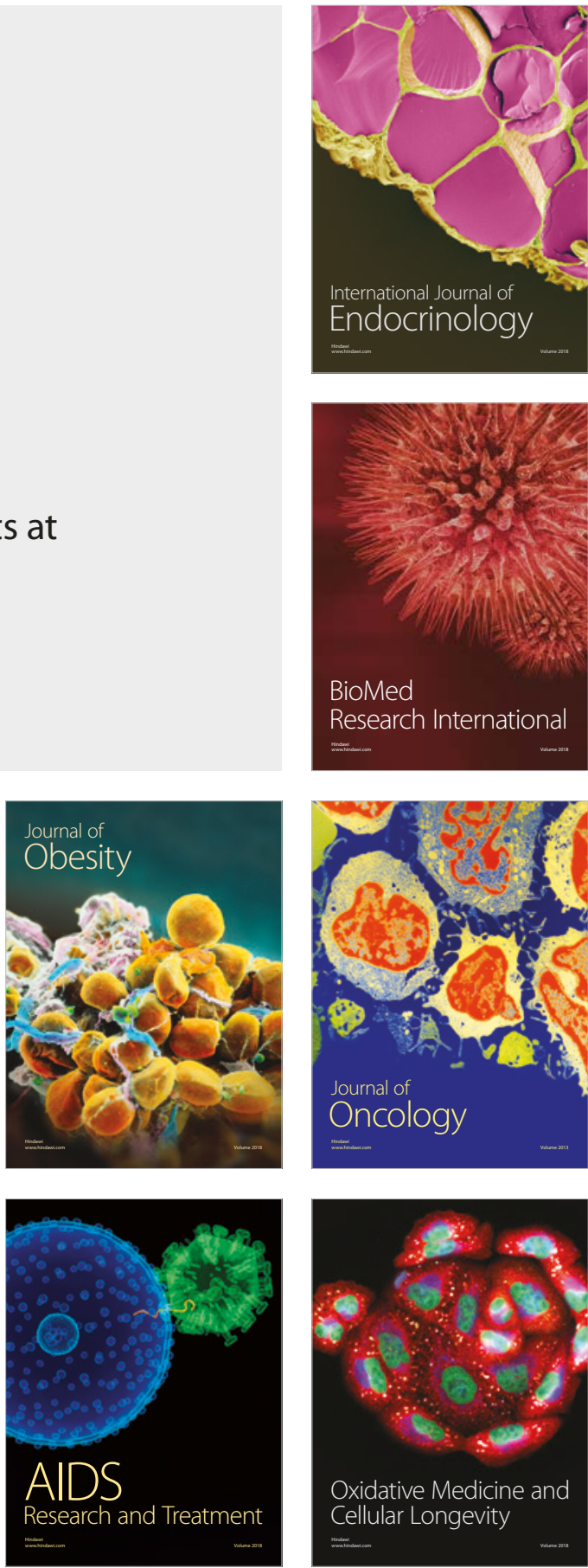